\title{
Ironic Strategies of Postmodern Art Games
}

\author{
Leonid A. Menshikov* \\ Saint-Petersburg State Rimsky-Korsakov Conservatory \\ 3 Teatralnaya square, St. Petersburg, 190000, Russia
}

Received 21.02.2018, received in revised form 22.03.2019, accepted 15.04.2019

Postmodernism has left a significant number of strategies to imitate art. They all rely on the game, offering to "play art". The way of existing in Postmodernism in the form of the game is possible due to the broad interpretation of the concept of the "game" in modern aesthetics. The game principle in the works of Baudrillard, Lyotard, Debord and Gadamer is absolutised as the basis of the social interactions within which art is created. The methodology of the postmodern games is worked out and at the same time turns into arbitrariness in science, everyday life and social life, depriving them of certainty and consistency, making the principle of process the most important quality of any activity, including artistic one. In the postmodern game, hyperreal, carnival and marginal features are outlined. It is the basis of imitation, combinatorics, pastiche and intertextuality as the text production strategy. As a result, a playing text appears, erasing any differences and hierarchies. The game appropriates the place of the sacred and parodying, declining and desecration become the leading forms of creativity. The game turns into a masquerade, acquiring performative-spectacular forms, performing the function of returning the past to the present, preserving the lost tradition. The game within the cultural framework defined the field of the unserious. The game that has swallowed up culture, deprives it of its seriousness, puts it beyond morality, making evil and death a thing of the past. The game allows Postmodernism to overcome the finality of art. Within the framework of the total playful nature of Postmodernism, the new avant-garde technologies of irony, nihilism, labyrinth, chaos, creativity, authorship, and representation are filled with new content.

Keywords: game, Postmodernism, irony, art, creativity, imitation, parody, carnival, marginality, art strategies.

Research area: philosophy; theory of art.

Citation: Menshikov, L.A. (2019). Ironic strategies of Postmodern art games. J. Sib. Fed. Univ. Humanit. soc. sci., 12(7), 1174-1190. DOI: 10.17516/1997-1370-0199.

Introduction into the research problem. The art of the second half of the $20^{\text {th }}$ century is characterised as an activity deliberately built on the game technology, which

(C) Siberian Federal University. All rights reserved

* Corresponding author E-mail address: 1mensch@mail.ru

This work is licensed under a Creative Commons Attribution-NonCommercial 4.0 International License (CC BY-NC 4.0). 
allows to speak about the so-called 'game world' of postmodernity. The game is a method of bringing novelty to postmodern texts and allows us to designate Postmodernism as a fundamentally new phenomenon in art, despite the fact that it does not allow any kind of innovation. The game nature of novelty in Postmodernism provides the basis for describing it as the 'culture of memory': the postmodern game is fundamentally different from other types and historical forms of game as it is 'a game with memory'.

The postmodern theory interprets the concept of the game broadly. If earlier the game was considered as the basis of artistic creativity (F. Schiller), as an effective way of social interaction of people (E. Berne), as a mechanism of language communication (L. Wittgenstein), as a source of culture (J. Huizinga), in the postmodern theory there is absolutisation of the game foundation of art and activity. This is observed primarily in the works by J. Baudrillard (Baudrillard, 2000), where game becomes an ontological category, a characteristic of being, included in the detection of temptation, and in the book by G. Debord (1999), devoted to the study of modern spectacularisation, in which he focuses on the introduction of gaming principle into society. In postmodern concepts, the game appears as a totally common form of being, providing a dialogue and interaction of diverse and contradictory tendencies. Postmodernism is characterised by one way of creating a new cultural reality, i. e. through "creating an intellectual game environment" (Malishevskaya, 2007: 9). This strategy had a decisive impact on the formation of the postmodern type of culture: at first, it worked as the strategy of creativity in various types of art, then became a universal cultural form. The movement took place from the selection of a special game dimension in aesthetics to its self-determination in other areas of social consciousness. The game dimension has appeared that is present in any fact of contemporary culture, showing a desire not to be oneself, i. e. not to remain serious, but once done, to continue to be embodied in various textual forms multiplying the culture's performance and setting a cyclical movement from repetition to repetition. Such a rhythm is typical for development in the postmodern culture.

Conceptological basis of the study. The game covers all spheres of life, it becomes the basis of social interactions. In the present day economic life, the game is an effective principle of overcoming difficulties and resolving economic problems: there are "many ways to beat it ... to transform severe material obstacles into completely surmountable obstacles for the mind, and then for the hands" (Astafyev, 1992: 67). The concept of the game is used in this and similar word structures, on the one hand, as a metaphor, and on the other hand, as a real cultural mechanism, allowing innovation to take place 
where tradition aggressively impedes it. There is a fundamental difference between the game as a method of existence of the postmodern culture and the game as a way of existence of contemporary society. In society, the game stipulates that "players are constantly struggling to change the rules in their favour" (Astafyev, 1992: 70), thereby destroying the essence of the game as a culture-creating principle, since the game, first of all, is the Rule, and today's situations similar to the given, make it clear that the game itself is played up.

The game acquires a significant role in science, where the same game rules work. Science as a way of being in culture with reliance on rules, stereotypes and procedures takes a game position. Its only difference from other forms of culture in the postmodern situation is that it continues to operate with the truth, which is absent, but claims to provide comprehensive knowledge of the subject. Science is becoming "a game with exhaustive information" (Lyotard, 1998: 126). In other forms of culture, this knowledge is conditional and partial, it can be built without the active affirmation of its genuineness, while in science the true idea of the world is played up. Because of this, science is becoming a sphere of game behaviour, actively transforming and developing rules, on which other players then rely. The rules of the game, which for science are only conditions for the extraction of truth, its criteria, beyond the framework of science, become the laws according to which cultural discourse unfolds in the game situation.

The game becomes a fundamental principle in everyday and social life. Everyday life is totalised, as all spheres of our life seem to become everyday life. We live feeling that nothing is happening to us, and we perceive the events of everyday life as the main events of our life, which, in essence, is life (or history) without events. The everyday life of modern man lacks tranquillity and monotony and begins to be arbitrarily designed by those who maintain it. Although such design is arbitrary only at first glance. Modern man is only externally free in their daily choice, but in reality people are completely absorbed and enslaved by the cultural experience of Western European culture, a civilization based on consumption. People actively build their daily space based on a set of samples provided by the consumer society, and play with them, projecting possible life situations and cultural stereotypes onto their own everyday life. We all play with images in our daily life creating a world that does not have a universal value, because it is a commonplace due to its belonging to the sphere of everyday life.

The growing role of the game in culture is defined as the simulation of sociocultural reality, leading to the creation of hyperreality, the true reality of the postmodern culture. Hyperreality is a game way to determine the principles and 
means of culture. The game becomes the dominant of Postmodernism regardless its rejection of cultural dominants. The postmodern hyperrealism of culture is "funded exclusively by the postmodern dominant, the game" (Goloborodova, 1999: 61). The game turns into a means that Postmodernism can count on in overcoming chaos, in attempts to transform from a theoretical project into a reality of culture. The game overcomes chaos and senselessness, makes it possible to navigate "in the conditions of lost semantic axis, which previously guaranteed this integrity" (Goloborodova, 1999: 61 ), in the disintegrated world of culture.

The game as a principle of hyperreality is devoid of productivity. It is not the result and not the goal that makes sense, but only the process itself. This is the nature of the postmodern culture. The game is procedural, it exists by means of living the reality it has created. The reality of the game has a structure and organisation parallel to the reality of the 'real' culture, but existing independently. Postmodernism also emerges as a cultural reality, originally built by analogy (in parallel) to the previous culture. It denies the previous historical situation, but does not cancel or forget it.

The world formed by the game is the alternative reality of Postmodernism in modern culture, the reality of conditional, relative values, which are not values, but rules. Due to its game nature, Postmodernism is "going beyond the borders of this life into a temporary sphere of activity" (Huizinga, 1992: 18), i. e. it is a fundamental attempt to build a new culture as a different one, but based on familiar patterns and meanings. Postmodernism is positioning itself as a confrontation of the existing cultural reality, both culture in general and a certain type of culture. It implements its inclusion in this reality: firstly, by origin and, secondly, because of the impossibility of breaking away from the family roots. It is forced to both resist and get involved, just like the game that "has the ability to reproduce within itself this confrontation and its own contrast with reality" (Fink, 1988: 380).

The postmodern game has a carnival tone. In the carnival it is made the universal quality of culture. The general dominants and principles of the game continue to function, but the game that has acquired universality can no longer be isolated within the culture as a marginal principle. The marginality of the game is forever gone. The game acquires an endless character, it cannot stop, because it cannot achieve the result that was peculiar to the carnival game, the return of culture to the 'normal' state. The game combines all the strategies of 'marginalisation' of the discourse that are demanded by Postmodernism. Irony, imitation, parody, pastiches and intertextuality are all aspects of game behaviour, which are "only pretending unserious utterances", although they 
have certain nuances of meaning. They provide culture with a redundancy of content that is located in the game field and is needed for a semantic shift to occur in the mind of the creator, ensuring the emergence of the concept. Postmodernism expands the list of game strategies, paying attention to ensuring the diversity of forms of the game in culture, while its previous cultural situations did not focus on the form of production of a particular utterance, but on its content and, ultimately, its meaning.

Statement of the problem. The postmodern type of creativity acquires the character of a reciprocal game: the author is playing using arbitrary and random discourses which have come to hand; the text is playing, showing meaning and revealing content that it does not contain; the voice of the narrator is playing, arising and disappearing depending on the situation of perception; the viewer is playing, receiving from the artistic text what it does not contain and does not imply. This is the principle of the existential game, which is arbitrary and has no ontological basis, which contains a combination of struggle (agon) and randomness (alea). This form of creativity reveals the transformations of carnival features that occur in the postmodern game.

The postmodern game, like the carnival, represents a mask worn by culture. Like other games, it is "emphasising its difference from the rest of the world with all kinds of disguises" (Huizinga, 1992: 17), it allows to hide secret meanings. Seriousness disappears behind the mask, sacral and vital forms are hidden and distorted, as they should not be accessible to the uninitiated. Hiding the true essence, the mask demonstrates a total and all-embracing laughter, mockery of the sacred, that is why it is so relevant in the postmodern style. Although the mask, which in Postmodernism is bright and catchy images of the mass language, is worn during the game with a certain effect. The postmodern mask is devoid of the ecstatic and simple-minded features of the carnival game; it hides the subtle grin of the encyclopaedic connoisseur summing up the history. It is that one who plays in the postmodern culture wearing a mask, who is aware of immersion in the cultural tradition, and not the one who wants to express themselves freely and independently. Masks in Postmodernism are not worn by people, but by the text, which is an expert encyclopaedist. The text plays participating in the carnival and putting on a variety of masks. The playing text is a total postmodern cultural form that absorbs all other cultural phenomena.

The reason for this is a change in the relationship between official and unofficial culture, the culture of the top and the bottom. In a globalised society, the division into the sacred and the profane has been lost. It is completely lost: in terms of space (sacred places disappear due to the total development of space by man), time (there is no time 
for ritual, carnival), and in social terms (social differences and hierarchies are largely erased). As a result, the game origin, inherent in the sacred areas of the cultural space, spreads and appropriates the role of the sacred. Since the sacred is dissolved in the world of modern culture, there is its parody, decline and reproach in the game. Therefore, Postmodernism is a permanent game carnival, more and more 'exhausted' and losing the remnants of sacredness because of its permanent nature. The game remains the same game, although it assumes the functions which are historically unusual for it. The result is the impossibility of completing the game: every cultural event within the framework of Postmodernism takes on the features of mirroring, i. e. it reflects the successive one, which again restarts the unfinished game. Dressing up and putting on masks on previous characters occurs.

The widespread understanding of the game as a masquerade forces us to draw the line between the beginning of the postmodern culture and its performative-spectacular form. The definition of the postmodern society as a society of the spectacle, given by G. Debord, or (which has a fundamentally different meaning) as a society acting according to the principles of spectacle, does not allow to reduce the postmodern game to a spectacle. The spectacle is, of course, a game, a game according to the rules, in which actors who are deprived of independence participate, playing in accordance with a scenario before indifferent and weak-willed viewers, the violation of which is impossible. Improvisations only emphasise the lack of freedom and the inability to go beyond the text. The postmodern society, as a spectacle, is deprived of the possibilities of game behaviour that are relevant in the postmodern art. The game, albeit within the framework of the rules, gives much greater freedom. It can be combinatorics, a quotation arising by means of a random allusion, pastiche through a parody comparison of meanings. Any means of forming an image in the postmodern world are wider and more independent than the reality of the spectacle. The society of the spectacle is a game, but the game is not the spectacle.

It is also the case with the possible reduction of the game to the performance. The postmodern game has demonstrative manifestations. It can be understood as a fragment of an unauthentic (game) reality and serves as such a view in discovering new meanings of this reality. The game principle is aimed at achieving new results each time basing on the same initial data and rules. The same is the essence of performance: presenting this or that reality, to discover its well-known sides so that they look like unknown ones. The performance takes place according to the game principle, but the game in no way comes down to performance. Its purpose is not to represent the rules, 
but to carry out the action according to the rules. Therefore, the game principle, and not the principle of the performance, is basic for Postmodernism. The postmodern game world is bigger than the real world of the present culture.

Methods. The confrontation of the world of Postmodernism and the world of culture was studied by J. Baudrillard, who defined the game as the unreal reality of the rules, opposed to the true reality regulated by law. Such fake reality "plays on the immanent relationship of arbitrary signs" (Baudrillard, 2000: 230). The rules set a temporary model of activity limited in application that exists only in a given situation of cultural perception. They do not appeal to eternity and to universal final meaningfulness and expediency. Using the rules is a characteristic feature of the simulation, i. e. the process in which production is lost, and the culture stops producing the real and begins to engage in a symbolic exchange of signs. Such an exchange takes place in accordance with the rules, the players who understand the essence of the process implement it, and the result is always not a real product, but only a symbolic one. The simulation is possible because its participants behave like players, i. e. they are aware that the process taking place is not real (they make actions that take place as if for fun). The participants of the simulation show off as they realise that the activity is fake, but pretend that everything that happens is serious, like in a game. The course and result of the simulation as a game is well known, and its meaning is not in the result, but in the symbolisation of human activity occurring in its course. According to Baudrillard, the game in Postmodernism becomes a general principle that determines the appearance and style of culture, setting the basis for the unity of other cultural forms.

H.G. Gadamer understands the duality of the game similarly to Baudrillard. He reveals the game through "the concept of moving back and forth", which is "central to the essential definition of the game" (Gadamer, 1988: 149). Herewith the principle of the pendulum is revealed, which is at the basis of the principle of the game: the maximum effort, excitement, and enthusiasm set the rhythm of the movement without a goal, which forms the active basis of the game. Game movement is carried out from tension to meaninglessness. Pendulum mechanism provides it with dynamic, does not allow it to fade. This mechanism is a constant repetition, moving "back and forth", which the postmodern culture uses as the basis for its development: repetition of the past in order to revive the future that comes at the expense of "returning memory". Memory returns culture into the past, that is why Postmodernism denies the subject, declaring its death. As the game plays by itself, so does the postmodern culture speak 
with history, not being the result of the intention of the subject, but shaping them as the game shapes the player.

Hermeneutics connects the game nature of the postmodern culture with the mechanisms of language existence, since Gadamer said that language is a game. Any fact of language - both a word and a statement — is never identical with itself. Language requires memories of other, prior meanings. The game works the same way, as it never preserves the authenticity of the situation, but is always in the position of catching up, recalling the facts of the past, the facts of the previous culture. Postmodernism, which blurs the boundaries of any established meanings, successfully uses this ability of the game, which it shares with language, i. e. to elude the definiteness of the meaning. This ability allows the game to increase knowledge. Just as in language, the result of speaking is not equal to the process or concept (it always gives rise to novelty, independent of the speaker, independent of the speech creator), so the result in the game does not fully reflect the concept, attitude and rules. The result is always unexpected for someone; it is an increment of meaning. This feature of the game determines the creative postmodern line that is striving for innovation, which Postmodernism seeks to deny: "the game's presentation reveals what is there" (Gadamer, 1988: 159). "What is there" is hidden and not obvious to the player before the start of the game. The game makes the culture to actualise the hidden meanings, in fact, to recall what was previously unknown. It reveals and turns them into cultural reality.

Another antinomy of the game is interpreted by Gadamer through the serious category: "that which represents only the game is not serious". On the other hand, "the game has its own and even sacred seriousness" (Gadamer, 1988: 147). Inner severity and apparent frivolousness are also characteristic of Postmodernism; they confirm the gaming essence of this phenomenon. This antinomy allows to look at Postmodernism as a threat, the same way as it allowed to see danger in the game. The danger lies in the fact that, similar to the game that does not pay attention to morality, but is guided only by rules (if rules are observed, the player is morally invulnerable, if they are violated, the player is condemned, but the rules themselves are morally neutral), Postmodernism is also guided only by the rules of generating cultural discourse turning a deaf ear to the moral problems of the $20^{\text {th }}$ century. The player (and the person of the second half of the $20^{\text {th }}$ century) is exempt of responsibility as long as they follow the rules. Following the rules, they may not think about their responsibility before being. Therefore, Postmodernism is "irresponsibility" (Tulchinsky, 1999: 35-53). Real responsibility in the game and in Postmodernism is weakened, it is only simulated by prescribed 
conditional punishment in which "a parody of reality is played" (Baudrillard, 2000: 260). The game does not allow the experience of what happened as affecting life values, and therefore sets the model for life outside moral constants putting a person outside morality.

While the game was a part of culture, only a peculiar, largely marginal sphere of it, the person perceived the existence "out of morality", but within the game as a temporary test. Postmodernism represents an attempt to turn this existence into real and permanent, creating the appearance of non-authenticity. The forerunner of Postmodernism is F. Nietzsche. The total spread of the game principle creates a game attitude to morality, i. e. it forms "a culture outside morality". Such a culture cannot be serious, since it is devoid of absolute responsibility, responsibility to the eternity. Therefore, Postmodernism as "culture after history" or "culture after death" is a game with the eternal. The game as the essence of Postmodernism makes it possible to deny death. The game is opposed to death as a factor in the uniqueness of culture in its completion, the game "inevitably gets stuck on the theme of death" (Goloborodova, 1999: 62). The game does not allow culture to end, even if it already has no reason to live. Such a role of the game in the postmodern culture cannot be fully realised, since "the game can mask the grief, save the fear of death from the fatal tragedy, but it cannot overcome it" (Retyunskih, 1998: 96). The game in the postmodern era is becoming the most important remedy for the absurd. The saving irony of the game may be the only way to solve the riddle of meaninglessness that has engulfed the life of culture. Therefore, the postmodern game gets into the position of cynicism, which begins to deny the rules, relying on their lack of obligation. The cynical attitude denies the game and should lead to its final stop, and therefore the postmodern cynicism, in turn, gets into the position of irony. This reveals the deep inconsistency of the game. It is both an ironic overthrow of established values, pushing them to de-hierarchisation, introducing them into the state of chaos, and at the same time, it is the only way to escape from chaos, because it gives efficiency to Postmodernism, which pushes forward, makes one to develop, change and grow. Playing by the rules and the ironic view are sufficient determinants that define the direction of cultural development. The game of irony brings creativity in Postmodernism, which Avant-garde was deprived of and which Postmodernism itself categorically denies in theoretical arguments.

Postmodernism needs the game in order to overcome its finality, when the postmodern world perception acquires absolute seriousness, when we recognise Postmodernism as the only possible continuation of development. Therefore, the game 
acquires a total character absorbing all other phenomena. Everything becomes a game. The reality of Postmodernism is the reality of the game. Simulative reality operates on the principle of the game. Virtual reality is also just a game of reality. Irony, simulation and virtuality are only forms of the postmodern game. These forms turn into ways to return, to make forgotten and therefore unknown meanings actual. The game helps to turn an infinitely elusive and fleeing culture into the wealth of the present. The present swells, becomes denser and richer due to the return of the meanings of the past, with the result that the whole past is made modern. This return is only possible in the game, otherwise Postmodernism will be unsuitable for life. Therefore, Postmodernism is a culture of returning memory.

Discussion. Irony. A significant aspect of the relationship of Postmodernism and game practices is irony. The ironic nature of Postmodernism has long been beyond doubt: "Postmodernism is the answer to Modernism: since the past cannot be destroyed, because its destruction leads to dumbness, it needs to be rethought ironically, without naivety" (Eco, 2007: 77). Irony is often interpreted as a form of the game. This is especially characteristic of literary studies, which, starting with ancient and medieval rhetorical treatises, define irony as a word game. Given the textual and verbal nature of the postmodern discourse, it can be argued that play and irony in postmodern are synonymous. Postmodern works on the principle of the game thanks to the discovery of its linguistic nature. Just as language and speech are different, the rules and the result of the statement, the game model and the game culture must differ. Postmodernism is based on the rules formed by tradition over the centuries. Its existence results in their ironic playing out, which can be called a postmodern culture and which happens by itself, regardless of its carrier, as a real "statement" of the existing system of rules. Just as in Gadamer's theory "a true conversation always turns out to be not the one that we wanted to lead" and "that it turns out in a conversation that ... no one knows in advance" (Gadamer, 1988: 446), in modern realities the game principle of culture-genetic activity is carried out. We have learned the rules, i. e. the heritage and codes of world culture, and they talk to us, playing and leading to an unpredictable result. Since the result of the game cannot be known in advance, it is random. The randomness of the game makes it an attractive activity that can answer all the questions of being, solve all riddles, resolve all contradictions and help a person to find a way out of the cultural crisis. The attractiveness of the game principle makes it the all-consuming basis of Postmodernism.

Danger of nihilism. Although it also implies danger, as "culture built on the game, begins to lean toward nihilism, toward the game of everyone with everything and 
everyone. The loss of the Absolute, whether it is God or absolute values, the game with which is impossible or criminal, leads to the loss of vital support" (Apinyan, 2003: 358). This is the inconsistency of the postmodern nature of the game: it lost the idea of the absolute, experienced the accessibility of the universe, but without fully understanding it, having no experience of serious treatment with it, it found the only way to master it, i. e. through the game, like a child. The childishness of the postmodern culture is the other side of its tragedy; they cannot be separated. There is a new discovery and development, of the world, which turned out to be completely unknown to humanity. It appears to be extremely dangerous and puts humanity on the brink of survival, bringing new and new evils. Humanity though, not seeing danger, continues to laugh loudly, simply and naturally, like a child. Laughter accompanies the postmodern game, its ease lies behind the textual definiteness of the culture, which turns it into an irony that still contains laughter, but already in a distorted form, and then into pastiche - such an irony in which laughter is preserved and loses its life. The pure, uncomplicated laughter of classical culture turns out to be impossible, because it is the laughter that is born out of any inconsistency with the ideal, but without the desire to evaluate it and to sentence it. Another laughter is born, a laughter from scratch, a mocking laughter: "total displacement and self-value game give rise to mockery. All meanings are assigned, but neither is its own" (Apinyan, 2003: 358). Such a shifted view corresponds to postmodern laughter, for which there is no ideal. This laughter is based not on comparison, but on shifting the meaning, i. e. empty irony. In an ironic aspect, the postmodern nature of the game becomes apparent. Consciousness today works according to the game principle: it sees the rules in everything, but acts variably. In this sense, the game is the only way to demonstrate relation to the world. It is based on a permanent implication: to think one thing and to say another; to think one thing and to do another, and this is irony.

Labyrinthicity. The way of thinking of the postmodern person acquires labyrinth features (since irony is "peculiar to the labyrinth consciousness" (Lyubimova, 1980: 27)), seeking to confuse the interlocutor in bends and strays of thought. The image of the labyrinth, which has become one of the symbols of the postmodern culture, is a reflection of an ironic attitude that avoids direct expression of thought, but always seeks to transfer it to another, parallel image, to another, parallel thinking world. The ironic person is in a state of constant wandering through the labyrinth, since they are unable to formulate a thought otherwise than ambiguously, and introduces a listener into this labyrinth, who will have to unravel the secrets and riddles of the discourse 
given to them. Wandering through the labyrinth, the aim of which is guessing, leads to the fact that the one who tries to find the answers, starts to share the ironic view of the world and joins the global postmodern game. In such a game, the positions of the players are balanced, they enter the field of chaos, since it is historically impossible to determine its temporal boundaries: it is not clear where the beginning of such a game is, and whether it will have an end.

Chaos. The irony of the players playing in relation to each other, once started, is unlimited. The game destroys itself: remaining a game outwardly, it overcomes the model of the classic game it begins with, turning into a chaotic game. The chaotic postmodern game is not one game, but games intersecting, interlacing and overlapping each other. What they preserve is the principle of playful behaviour, but the unity of an autonomous game with a goal in itself is lost. The postmodern game "is imposed on man, it decentres their self, dehierarchises their system of values, turns the microcosm into a microchaos" (Konovalova, 2005: 129). The game, which served as a means of ordering chaos, harmonising human life in culture, being a way of recreation, removing destructive, chaotic and anti-cultural moments into the sacred space, is now itself based on a chaotic principle and acquires a centrifugal potential leading to fragmentation. Nevertheless, in Postmodernism the game is a means of searching for meaning, even if it cannot be final, it cannot be unique and absolute, but it arises precisely in the game as the illumination of the world with a new random meaning existing within the framework of the established rules guiding us along the game.

Impossibility for creativity. The unity of the game and irony is most evident in art. This suggests that "art becomes a game" (Ortega y Gasset, 2002: 260). The game allowed art to overcome the destructive pathos that it has acquired as a result of the collapse of the classical value system in the era of romanticism and the birth of nonclassical aesthetics, which was quite negativistic. Through the game, the irony has returned to the postmodern culture, having suffered a crash within the framework of a romance project. It was able to revive and become a cultural value due to the game that allowed it to forget the former seriousness of Avant-garde and Modernism. New irony prescribes "to look at art as a game ... as a mockery of oneself ... New art makes fun of art itself" (Ortega y Gasset, 2002: 262). In the postmodern game, the classic opposition of irony to high comic and clown ridicule as low comic described by Aristotle, is removed ("irony has a more noble character than clownishness, because in the first case a person turns to a joke for his own sake, and the clown [makes it] for the sake of others" (Aristotle, 2000: 147)), which allows them to merge into a 
single element of the postmodern game. The game shows its nature and as the basis of creativity in general. The game essence of creativity is manifested most fully in the postmodern art. Moreover, it is not only a language game that lies at the heart of culture as a whole, the game that reveals culture as "the process of language games, sorting and selecting cultural languages and their combinations" (Lipovetsky, 1992: 215), but also a real game that takes place in the life of an artist and the constituent content of the creative process. In this case, the game does not turn into juggling with cultural meanings, dressing up and recombining actual expressions, picking up a new grammar of cultural and artistic languages from existing word elements, but remains a form of activity within the framework of culturally determined rules. Behind the game there is necessarily a general principle defining the goal and the purpose, which provides postmodern creativity with meaningfulness and purposefulness: in any creative act there is a "concept ... which requires ... a choice of stereotypes" (Mitta, 1989: 68). The game gives creativity limitless possibilities, because it allows it to be outside the framework of style, which has previously always restricted the artist's freedom to standards, stereotypes, attitudes and tastes. The postmodern rejection of the stylistic relationship within art liberates them in the game. The artist has got the opportunity to implement an absurd, unpresented choice of means of expressiveness, and the game opened the artist "the way through ... cultures, sciences, languages, arts, centuries" (Hesse, 1984: 159). Creativity has lost its totalitarian colouring, which was inherent in it before. It has ceased to impose its perception of the world on the perceiver.

Author and viewer. If earlier the viewer had to follow the author trying to trace and understand their intention, to determine their identity within the artistic world, now the viewer is free to simply join the game started by the author and continue it. They participate in building one or another (in fact, always the same, and always different) scenario of artistic creativity and its result. The game contributes to disappearing of the totalitarian dictatorship, which was previously carried out by the author, leaving the position of the teacher-dictator to the position of "a playing coach". Despite the totalitarian nature of any statement determined by poststructuralist criticism, the postmodern game attempts to engage the reader in the discourse as an interaction process in order to reduce the impact of the author's statement. The game becomes a volitional beginning of the postmodern culture, i. e. the principle that guides its development in a certain direction, since the subject is already deprived of such function. The game that has turned into the elements of cultural creation is the only guarantee that its results will be systematic. This is because the game is always played by the rules, and therefore, has a limited corridor 
in which it can be carried out. The game "reveals what is there" (Gadamer, 1988: 159), shaping the postmodern art. The process of the game determines the rules revealing the potential for self-disclosure in the heritage, revealing in it what is hidden and not revealed. Here the game always acts ironically, because irony is a statement with an implication that reveals the hidden, while leaving it unsaid. The game in each new action makes a statement in accordance with the rules that remain not fully played out, not fully used, they remain hidden, potential, unknown implications. It is irony and parody of the statement constantly present in the Postmodernism. The game provides opportunities that contain the rules, it gives a choice of realised situations; each of them is not real, but only potential as a creative model.

Representation and aura. This turns Postmodernism to the topic of representation, one of the key and essential components of the game model of culture. Expansion, presentation and demonstration of hidden opportunities are principles of the existence of the game as an ironic process. The game cannot but unfold, it is a verbal irony expressed in socially significant acts. The game finds itself as something that is different from being, but which is not radically different, since there is always an inseparable connection with the rule that enchains the freedom of the game. Thanks to the rules, the game does not create culture, but only introduces us into the context that defines the possible framework of being and interpretation. Here there is a limitation that allows the game to create a simulated reality, but does not allow it to exercise true creative freedom. Restriction is rooted in such a property of the game as the connection with "illusory, imaginary appearance ... with the goal of conquering the dimension of the magic" (Fink, 1988: 394). The game provides the prosaic borrowing, to which sometimes there is a desire to reduce the postmodern culture, with the magical aura, which turns it into the true one. This is the area of freedom that appears in Postmodernism due to the game, which occurs with genuine earnestness, which does not allow even for a second to doubt its reality. The area of freedom always remains extremely limited, since the game acts only within the framework of the space created by the game itself, as well as irony works only in the field it has created. Otherwise, its meaning will be unclear. The space of irony-game is the postmodern aura. The closeness of the game in itself is explained by the fact that the rule that ensures the authenticity, objectivity and purposefulness of the game is a "radical simulacrum" (Baudrillard, 2000: 241).

Conclusion. The specificity of representation leads to the fact that Postmodernism is perceived as "only the game", almost as a synonym for the game in art. It appears as a game leading to the debate about hits attitude towards modernity and Modernism. 
This attitude is still uncertain, and will never be determined due to the fact that Postmodernism plays with modernity, Modernism and Avant-garde, i. e. it does not need to have any clear position in relation to them, but it is much more profitable to react according to the principle of the game, as needed at any particular time, in different ways, situationally. Despite the fact that, theoretically, Postmodernism is opposing the previous historical epoch, neither its negation of modernity, nor its use are not forbidden by the rules of the game. This is the same form of the game in Postmodernism, the game that combines "destruction" and "teasing" (Apinyan, 2003: 102), which is largely competitive and agonal.

The game is also the principle of using the heritage of classical culture in various forms and in many different ways, including the manifestation of a combinatorial or mimic game. Postmodernism imitates in the game everything that comes into its field of vision, imitates including in its field of interest and creating strange and unprecedented combinations of existing realities.

Finally, another postmodern game, perhaps the main one, is related to how postmodern creative strategies emerged, what can be called "playing Postmodernism" and what arises the following question in this regard: "Are these facts and phenomena artefacts by mistake, misunderstanding or evil will of someone created artificially, invented and maintained by someone from self-serving motivations - that is, such that can be either multiplied or reduced, which can be encouraged or can be put an end" (Chuchin-Rusov, 1999: 25). Herewith, it is possible to exist in art today, only playing Postmodernism, with reliance either on occasion (as in the aleatoric game), or on fate (as in the existential game).

\section{References}

Apinyan, T.A. (2003). Igra v prostranstve ser'yoznogo [Game in Space of Serious]. Saint-Petersburg, Publishing House "Izdatel'stvo Sankt-Peterburgskogo universiteta", $398 \mathrm{p}$.

Aristotle (2000). Ritorika. Poetika [Rhetoric. Poetics]. Moscow, Publishing House "Labirint", 224 p.

Astafyev, Y.U. (1992). Postmodernizm v poznanii obschestva [Postmodernism in Consciousness of Society]. In POLIS. Politicheskie issledovaniya [POLIS. Political Studies], 3, 63-71.

Baudrillard, J. (2000). Soblazn [Seduction]. Moscow, Publishing House "Ad Marginem", $319 \mathrm{p}$. 
Chuchin-Rusov, A.E. (1999). Novyj kul'turnyj landshaft. Postmodernizm ili neoarhaika [New Cultural Landscape. Postmodernism or Neoantiquity]. In Voprosy filosophii [Issues of Philosophy], 4, 24-41.

Debord, G. (1999). Obschestvo spektaklya [The Society of the Spectacle]. Moscow, Publishing House "Logos", 224 p.

Eco, U. (2007). Zametki na polyah "Imeni rozy» [Postscript to The Name of the Rose]. Saint-Petersburg, Publishing House "Simpozium", 92 p.

Fink, E. (1988). Osnovnye fenomeny chelovecheskogo bytiya [The Main Phenomena of Human Life]. In Problema cheloveka v zapadnoj filosofii [Problem of the Person in the Western Philosophy]. Moscow, 387-403.

Gadamer, H.-G. (1988). Istina i metod: Osnovy filosofskoj germenevtiki [Truth and Method: Fundamentals of Philosophical Hermeneutics]. Moscow, Publishing House "Progress", 704 p.

Goloborodova, T.N. (1999). Igra v kul'ture postmodernizma [Game in the Culture of Postmodernism]. In Definitsii kul'tury [Culture definitions]. 4, 59-64.

Hesse, H.K. (1984). Igra v biser [The Glass Bead Game]. In Palomnichestvo v stranu Vostoka; Igra v biser; Rasskazy [Pilgrimage to the Country of the East; The Glass Bead Game; Stories]. Moscow, 77-435.

Huizinga, J. (1992). Homo Ludens; V teni zavtrashnego dnya [Homo Ludens; In the Shadow of Tomorrow]. Moscow, Publishing House "Progress", 464 p.

Konovalova, O.A. (2005). Ironiya kak atribut kul'tury epohi postmoderna: Filosofskij analiz: Dissertatsiya ... kandidata filosofskih nauk [Irony as Attribute of Postmodern Culture. Thesis for the degree of PhD]. Kemerovo, 178 p.

Lipovetsky, M.N. (1992). Patogenez i lechenie gluhonemoty. Poety i postmodernizm [Pathogenesis and Treatment of a Surdomutism. Poets and Postmodernism]. In Novyj mir [New World], 7, 213-224.

Lyotard, J.-F. (1998). Sostoyanie postmoderna [The Postmodern Condition]. Moscow, Publishing House "Institute of Experimental Social Science"; SaintPetersburg, Publishing House "Aletejya", 160 p.

Lyubimova, T. B. (1980). Ponyatie komicheskogo v estetike [Concept «Comic» in an Aesthetics], In Voprosy filosophii [Issues of Philosophy], 1, 23-37.

Malishevskaya, N.A. (2007). Igrovye praktiki v diskurse postmoderna: Avtoreferat dissertatsii... doktora filosofskih nauk [Game practices in a Postmodern Discourse. Thesis for the degree of doctor in philosophy]. Rostov-on-Don, $30 \mathrm{p}$.

Mitta, A.N. (1989). V aspektah postmodernizma [In Aspects of Postmodernism]. In Iskusstvo kino [Filmart], 7, 65-79. 
Ortega y Gasset, H. (2002). Vosstanie mass [The Revolt of the Masses]. Moscow, Publishing House "AST", 509 p.

Retyunskih, L.T. (1998). Etika igry [Game ethics]. Moscow, Publishing House "Prometey", $120 \mathrm{p}$.

Tulchinsky, G.L. (1999). Slovo i telo postmodernizma: Ot fenomenologii nevmenyaemosti $\mathrm{k}$ metafizike svobody [Word and body of postmodernism: From insanity phenomenology to freedom metaphysics]. In Voprosy filosophii [Issues of Philosophy], 10, 35-53.

\section{Иронические стратегии постмодернистских игр в искусство}

Леонид А. Менышиков

Санкт-Петербургская государственная консерватория имени Н.А. Римского-Корсакова

Россия, 190000, Санкт-Петербург, Театральная площадь, 3

Постмодерн оставил значительное число стратегий имитации искусства. Все они опираются на игру, предлагая «играть в искусство». Такой способ существования в постмодернизме возможен благодаря расширенному толкованию этого понятия в современной эстетике. Игровой принции в работах Бодрийяра, Лиотара, Дебора, Гадамера абсолютизируется как основа сочиальных взаимодействий, где творится, в том числе, и искусство. Методология постмодернистских игр вырабатывается и вместе с тем обращается в произвольность в науке, бытовой и соииальной жизни, лишая их определенности и постоянства, возводя принции прочессуальности в важнейшее качество любой, в том числе художественной, деятельности. В постмодернистской игре обнаруживаются черты гиперреальности, карнавальности, маргинальности. Она лежит в основе имитации, комбинаторики, пастиша, интертекстуальности как стратегий производства текста. В результате возникает текст, стирающий любые отличия и иерархии. Игровое узурпирует место сакрального, ведущими формами творчества становятся пародирование, снижение и поругание. Игра превращается в маскарад, приобретая перформативно-спектакулярные формы, выполняя функцию возвращения прошлого в настоящее, сохранения утраченной традици. В рамках культуры она определяла поле несерьезного, а поглотив культуру, лишает ее серьезности, ставит вне морали, делает зло и смерть достоянием прошлого. Игра позволяет постмодерну преодолеть финальность искусства. В тотальном игровом характере постмодерна приобретают новую актуальность и наполняются новым содержанием привычные авангардные технологии иронии, нигилизма, лабиринта, хаоса, творчества, авторства, репрезентации.

Ключевые слова: игра, постмодерн, ирония, искусство, творчество, имитация, пародия, карнавал, маргинальность, творческие стратегии.

Научная специальность: 09.00.00 - философские науки; 17.00.00-искусствоведение. 